\title{
Ankara il merkezinde 2-10 yaş arasında görme yetersizliğine sahip olan çocukların demografik, tanılanma, eğitimsel ve aile destek özelliklerinin incelenmesi ${ }^{*}$
}

\author{
The study of the 2-10 year-old visually impaired children's demographic, \\ diagnostic, educational and family support characteristics in Ankara city \\ center
}

\author{
Hale Dere Çiftçi ${ }^{1}$
}

\begin{abstract}
Makale Geçmiģi
Geliş : 25 Temmuz 2018

Düzeltme : 17 Ağustos 2018

Kabul : 04 Eylül 2018

Çevrimiçi : 05 Eylül 2018
\end{abstract}

\section{Makale Türü}

Özgün Makale

\section{Article History}

Received : 25 July 2018

Revised : 17 August 2018

Accepted : 04 September 2018

Online : :05 September 2018

\section{Article Type}

Original Article
Öz: Erken çocukluk döneminde görülen görme yetersizlikleri, çocukların ve ailelerin yaşantılarını önemli derecede etkilemektedir. Bu çalışmada da görme yetersizliğine sahip 2-10 yaşlar arasındaki çocukların demografik, tanılanma, eğitim ve aile destek çalışmaları incelenmiştir. Araştırmaya 2-10 yaşlar arasında görme yetersizliğine sahip 51 çocuğun ebeveyni katılmıştır. Çalışmada tarama modeli kullanılmıştır. Görme yetersizliğine sahip çocukların ebeveynlerine anket uygulanmıștır. Görme yetersizliğine sahip çocukların çoğunun 0-3 aylar arasında fark edildiği ve aynı dönemde tanısının konduğu belirlenmiştir. Ebeveynlere görme yetersizliğinin nedeni sorulduğunda, kalıtım, annenin hamilelik döneminde geçirdiği hastalıklar ve enfeksiyonlar, kuvözde yatarken bebeğe fazla oksijenin verilmesi ve çocukluk döneminde geçirilen hastalıklar yanıtları alınmıştır. Ebeveynlerin görme yetersizliğinden şüphelenmelerine ve doktora gitmelerine neden olan davranışlar arasında en fazla çocuğun gözlerini aşırı şekilde ovuşturma yanıtı olmuştur. Araştırmaya katılan çocukların en fazla görme engelliler ilköğretim okuluna devam ettiği, 0-1 yaşlarından itibaren özel eğitim ve rehabilitasyon desteği almaya başladığı hem bireysel eğitimi hem de grup eğitimi aldıkları ve çalışma sırasında eğitim kurumunda eğitim modüllerinden en fazla Türkçe ve Matematik Modülü aldığı belirlenmiştir. Ebeveynlere aile destek çalışmalarına yönelik sorulan sorularda ise ebeveynlerin çoğunun aile eğitim çalışmalarına katıldığı ve çocuğa davranış şekilleri, çocukla iletişim, çocuğun gelişimini destekleme konuları hakkında eğitim aldıkları belirlenmiştir.

Anahtar Kelimeler: Görme yetersizliği; Görmeyen çocuk; Görme yetersizliği olan çocukların eğitimi; Aile eğitimi; Görme yetersizliği olan çocukların eğitim kurumları

Abstract: Visual impairment in early childhood affects children's and families' lives significantly. In the present study the demographic, diagnostic, educational, and family support characteristics of 2-10 year-old children with visual impairment are examined. 51 parents, whose children are visually impaired and between the ages of 2 and 10, participated in the study. The survey model was used in the study. Questionnaire was applied to the parents of children with visual impairment. It has been observed that most children with visual deficiency participating in the study have been recognized and diagnosed between 0-3 months. When parents were asked about what is told to them about their children's visual deficiency reason, their answers were as follows; inheritance, illnesses and infections during pregnancy, excessive oxygenation to the baby while lying in the incubator, and childhood illnesses. Parents' answers to the question "what made you suspicious about your child's visual deficiency and what were are behaviors that made you go to the doctor" the answer was seeing their children rubbing their eyes excessively. It was observed that parents mostly preferred elementary schools for the visually impaired ones, from 0-1 year old they preferred special education and rehabilitation support, most children were having both individual and group education, and mostly had Turkish and Math Modules in the schools they attended. About the questions related to family support practices parents' answers revealed that most of the parents have participated in family education studies about visual impairment. Parents have been identified as participating in family education regarding behavior patterns, communication and development. Keywords: Visual impairment; Blind child; Education of visual impairment children; Family education; Educational institutions of visual impairment children

\footnotetext{
* Erken Çocuklukta Müdahale Alanında Güncel Araştırmalar ve Yenilikçi Uygulamalar” Temalı, 2. Uluslararası Erken Çocuklukta Müdahale Kongresinde (29 Mart-01 Nisan 2018, ICECI,2018) Sözlü Bildiri olarak sunulmuștur.

${ }^{1}$ İstinye Üniversitesi, Sağlık Bilimleri Fakültesi, Çocuk Gelişimi Bölümü, haledereciftci@ gmail.com, ORCID: http://orcid.org/0000-00034524-4685
} 


\section{SUMMARY}

\section{Introduction}

Visual impairment from birth to six years causes children to undergo developmental backwardness and many inadequacies such as orientation, psycho-motor, cognitive, language and social skills (Tsai, Meng, $\mathrm{Wu}$, Jang and $\mathrm{Su}, 2013)$.

The most common causes of visual impairment include heredity, premature labor, tumor, diabetes, vascular diseases, lack of vitamin A and meningitis (Kaur et al., 2016; Tuncer, 2014). The symptoms of visual impairment in terms of appearance are strabismus or cross-eye, closing one eye, swelling in the eyelids, and recurrent infections, etc.; in terms of behavioral statements are rubbing or itching eyes constantly, closing one eye, being in need of additional time to complete the task, and excessive clumsiness etc. (Tuncer, 2014). Aamong complaints such as burning or blurred vision in the eyes, dizziness, blurred or double vision when doing a task or activity can also be indicated (Hallahan and Kauffman, 2003; Smith, 2001).

First, doctors diagnose visual problems and then parents and other caregivers. It can usually be diagnosed during the first four months of life (Kiarie, 2004). Psycho-motor, self-care, daily life skills, independent mobility skills, social skills, Turkish and mathematics modules are applied for children with visual impairment (MEB, 2013).

It is important to support the development of children with visual impairment and to include family members in their education. Mothers and babies may have difficulty noticing each other's initiatives to maintain interactions of efficacy, emotion, and behavioral cycles (Nergiz, 2013).

In the present study demographic information, recognition of visual impairment, education of these children and family support activities are examined.

\section{Method}

The study was conducted at ten voluntary special training centers in Ankara and 51 parents participated. "Demographic, Diagnostic, Educational and Family Support Information Form for Children with Visual Impairment" was prepared by the researcher for these parents. The study is a descriptive one. While analyzing the data, percentage, frequency and $\mathrm{x}^{2}$ statistics are used.

\section{Results}

It is seen that more than half of the children participating in the study were boys and most of them between were 8-10 years old. It is noteworthy that most of the children were blind, and those who had poor sight were having problem in both eyes. It is seen that the majority of the mothers who participated were primary school graduates and the fathers graduated from high school or in schools the same level. Parents were mostly between the ages of 31-40, the majority of the mothers were housewives and the majority of the fathers were workers or civil servants. 
In the majority of children with visual impairment no visual impairment was found in the family or relatives. The visual impairment in children has been diagnosed by the doctor as early as 0-3 months, and the caregivers were the next ones diagnosing the visual impairment via children's behaviors. While the majority of blind children are diagnosed between 0-3 months, it is observed that children with poor sight are diagnosed between 4-6 months.

The reasons of visual impairment was mainly heredity, illnesses and infections that the mother had during her pregnancy, excess oxygen in incubator and childhood diseases. It is noteworthy that parents noticed their babies' visual impairment at the ultrasound during the pregnancy period and when their children rub their eyes excessively it also gave them a clue about the impairment.

It has been determined that children with visual impairment attend primary schools for the visual impaired children, most of them begin to receive education from 0-1 years of age, and most of them benefit from both individual and group education. It has been determined that children with visual impairments continue mostly to Turkish and Mathematical Modules.

It is seen that parents participated in individual family education workshops in special education and rehabilitation centers where their children attend mostly after learning that their children has visual impairment. Most of the parents have indicated that they are involved in family education studies on child behavior, communication with children and supporting the child's development.

\section{Conclusion and Discussion}

In the study it is found that most children with visual impairment have no visual impairment in their family history and diagnosed as early as 0-3 months of visual impairment. It has been observed that the visual impairment is noticed by an ophthalmologist. Solebo and Rahi (2014) stated that pediatricians and pediatric specialists have also an important role in early diagnosis early detection of visual impairment. Muhit, Shah, Gilbert, and Foster (2007) also found that vitamin A deficiency is the main cause of childhood visual impairment. Although many studies have identified many reasons for the causes of visual impairment, the most important causes are inheritance and lack of vitamin A. The first cause for visual impairment is found as inheritance. Parents' stated that the excessive rubbing of the eyes that they observed in their children gave them a clue about something was going wrong. Özyürek (1998) also stated that there is a high risk of visual impairment in children when the following symptoms are seen; not being able to follow or notice an interesting item close to them or right in front of them, looking at the same place for a long time and rubbing or itching eyes frequently.

Most of the parents who participated in the study attended family education studies. Giangreco et al. (1991) found that parents of children with visual and hearing impairment should be supported in terms of "curriculum, education, cohesion and parental communication". It has been found that most of the parents have participated in family education studies conducted in special education and rehabilitation centers that their children attended and the education is mostly given by the visual impairment teachers. 
The topics that parents most need and are trained with are the ways in which children behave, how to communicate with their children, and how to support their children's development. Murdoch (2002) conducted a study with children who were blind and deaf and emphasized the need to prepare programs focusing on parent-child interactions, family support and parents' active participation in education. 


\section{GİRISs}

Çocukların çevrelerini tanımada en fazla kullandıkları duyulardan biri görme duyusudur. Çocuklar çevresi hakkındaki bilgi edinirken, bilgilerinin \%75'ini görme duyusunu kullanarak edinirler.

Yasal tanımlamaya göre görme yetersizliği, tüm düzeltmelere rağmen 20/200'lük görme keskinliğine ya da daha azına sahip olan ya da görme açısı 20 dereceyi aşmayan kişilere görmeyen/kör, görme keskinliği 20/70 ile 20/200 arasında olan kişilere ise az gören denmektedir (Howard, Williams ve Lepper, 2011).

Çocuklarda görülen görme kusurları ya da yetersizlikleri çocukların çevresinden bilgi edinmesini ve günlük yaşamlarında birçok sorun yaşamalarına neden olmaktadır. Doğumdan altı yaşına kadar ortaya çıkan görme yetersizlikleri, çocukların gelişimsel olarak geri kalmalarına, yönelim, psiko-motor, bilişsel, dil ve sosyal beceriler gibi birçok alanda yetersizlik göstermelerine neden olmaktadır (Tsai, Meng, Wu, Jang ve Su, 2013; Wiskochil, Lieberman, Wilson ve Petersen, 2007). Görme yetersizliği olan çocuklarda 15-27 aylarda sıklıkla sosyal etkileşimlerinde azalma ve tekrarlı şekilde vücudunu sallama, el ve parmak hareketleri, yüzünü buruşturma, gözünü ovalama, bastırma ya da kaşıma gibi streotip (tekrarlanan) davranışlar dikkati çekmekte, bunu da daha yavaş öğrenme izlemektedir (Dale ve Sonksen, 2002; Fazzi vd. 1999; Hallahan ve Kauffman, 2003; Smith, 2001).

Görme yetersizliği olan çocukların hareket gelişimindeki yavaşlık, bu çocukların daha az deneyim yaşamalarına neden olmaktadır. Göremedikleri için bulundukları ve tanıdıkları yer dışındaki mekânları kavramada güçlük çekmektedirler. Az gören çocuklar ise doğrudan ve tesadüfi görsel deneyimlerden ya da bir görevi planlama ve yürütmek için görmeyi kullanabilmektedirler (Heward, 2000; Kirk, Gallagher ve Anastasiow, 1993). Görmeyen bebeklerin özellikle kavrama, uzanma, yuvarlanma, emekleme, yatar pozisyondan oturur pozisyona geçme ve merdiven inme-çıkma gibi birçok becerilerinde gecikme görülmektedir. Görmeyen çocuklar çevresindeki nesneyi tanımak için nesneyi avuçlayarak kavramakta ya da avuçlayamayacağı büyüklükteki nesnenin farklı kısımlarına dokunarak, nesneyi tanımaya çalışmaktadır. Görmeyen çocuklar, ayaklarını ayrı tutarak ve kollarını yanlara açarak yürüme gibi duruş bozuklukları ya da yürürken duvara çarpma gibi sorunlar da yaşayabilmektedir. Bu nedenle bu çocuklara yürüme öğretilmektedir (Allen ve Cowdery, 2005; Haibach, Wagner ve Lieberman, 2014; Hallahan ve Kauffman, 2003; McAllister ve Gray, 2006; Prechtl, Cioni, Einspieler, Bos ve Ferrari, 2001). 
Görme yetersizliği, çocukların çevresini keşfetmesi ve anlamasında güçlüklere neden olmaktadır. Görmeyen bebekler gören akranları gibi uyarıcıları algılayamamakta ve öğrenme olanakları da sınırlı olmaktadır. Gören bir bebek, işitsel bir uyarıcıya ya da kişiye döner, onu inceler ve vücudunun bölümlerini hareket ettirirken, görmeyen bebekler işitsel uyarıcıyı duyduğunda sese dikkatini verdiğinden dolayı bir süre hareketsiz kalmakta ve nesnenin varlığını ve yerini bulmaya çalışmaktadır (Farrenkopf, Howze ve Sowell, 1995; Kirk, Gallagher ve Anastasiow, 1993). Gören çocuklarda bir buçuk-iki yaşlarında gelişen nesne devamlılığı, görmeyen çocuklarda üç-beş yaşlarına kadar gelişememektedir (Ferreira ve Albuquerque, 2017; Heward, 2000).

Görme yetersizliği olan ya da görmeyen çocuklar görsel bilgileri eksik, parçalanmış ya da yanlış algılarlar. Bu görsel bilgilerin eksikliği de özellikle erken dönemde dil gelişiminde gecikmeye ve değişikliklere neden olmaktadır. Görmeyen çocukların ilk kelimelerini söylemeleri daha uzun zaman almaktadır. Ayrıca, gören çocukların ilk aşamada kelime hazinelerinde görülen “orada", "daha fazla", “yukarı", "hepsi bitmiş" gibi işlevsel kelimeleri görmeyen çocukların kelime hazinesinde bulunmaz. Görmeyen çocuklar kendi cümlelerinden çok anne babasından işittiği cümleleri kullanmaktadırlar. Görmeyen birçok çocuk "ben" ve "sen" gibi zamirleri kullanmakta ve anlamakta güçlük çekmekte, kendisinden başka biriymiş gibi "sen” diye ifade etmektedirler (Lewis, 1987).

Görme yetersizliği olan çocukların çevresindeki insanlarla sınırlı iletişim kurarlar, genellikle akranları tarafından dışlanırlar ve çevresindeki diğer bireylerin farkında oluş düzeyleri yetersizdir (Liberman ve MacVibar, 2003; Lima ve Nunes, 2015; Lo'Pez-Justicia, Marti’Nez ve Medina, 2005). Görme yetersizliği olan bebek ile ebeveynleri arasında duygusal ifadeleri anlamalarında önemli olan göz kontağı kurma yer almaz. Görmeyen bir çocuğun göz kontağ kuramayışının ve yüz ifadesinin olmayışı ebeveyni ile arasında iletişimin yetersiz olmasına neden olmaktadır. Göremeyen bebekler çevrelerine karşı ilgisini, yüzünden "düşürdüğü oyuncağı çevresini elleri ile yoklayarak arama" gibi elleri ile ifade etmektedirler (Lee, Kotsopoulos ve Stordy, 2012; Varol, 1996).

Görme yetersizlikleri birçok nedenle ortaya çıkmaktadır. En sık görülen görme yetersizliklerin nedenleri arasında kalıtım, prematüre doğum, tümör, diabet, damar hastalıkları, A vitamini eksikliği ve menenjit sayılabilir (Gilbert ve Foster, 2001; Kaur vd. 2016; Kirk, Gallagher ve Anastasiow, 1993; Tuncer, 2014). Ayrıca annenin hamilelik döneminde ateşli bir hastalığa (kızamıkçık vb.) yakalanması, bazı ilaçlara veya röntgen 1şınlarına maruz kalması da görme yetersizliklerinin nedenleri arasındadır. Erken doğum sebebiyle oksijen desteği verilen 
bebeklerde oksijen miktarının fazla verilmesi sonucu bebeğin retinasının zarar görmesi; doğum sonrasında geçirilen ateşli hastalıklar, kazalar veya zehirlenmeler, kızamık hastalığının korneada körlüğe neden olması, keratiteye (kornea iltihabı) maruz kalma, herpes, ikincil enfeksiyonlar gibi etkenler de görme yetersizliklerine yol açmaktadır (Baş, 1993; Gilbert ve Awan, 2003; Özyürek, 1998).

Görme yetersizliğinin fark edilmesi ve görme yetersizliğinden şüphelenilmesine neden olan belirtiler gözlerin görünümü, çocuğun bazı davranışları ve göz şikayetleri şeklinde gruplanabilir. Görme yetersizliklerinin görünüm açısından; gözlerde şaşılık veya kayma, bir gözünü kapatma, göz kapaklarında şişme ve tekrarlayan enfeksiyonlar, gözlerde kızarıklık, kaşıntı, çapaklanma, iltihaplanma ya da sulanma, flaşla çekilmiş fotoğraflarda kırmızı göz yerine beyaz yansımanın olması gibi belirtiler dikkati çekmektedir. Görme yetersizliğinin davranışsal belirtileri arasında; sürekli gözünü ovuşturma, bir gözünü sürekli kısma ya da kapatma, okuma materyallerini yüzüne çok yakın tutma, okurken sürekli olmayan kelimeler ekleyerek okuma ve yazma, okurken parmak ve kalem gibi işaretleyerek okuma, harf ve sayıları yazmada güçlük, akademik başarısızlık, sosyal ve fiziksel aktivitelere katılmada isteksizlik, renkleri tanıma ve renk uyumunu belirlemede güçlük, duyusal algısal koordinasyonla ilgili problemler, görevi tamamlamada ek süreye ihtiyaç duyma, insanlarla konuşurken göz kontağı kurmada güçlük çekme ve aşırı sakarlık sayılabilir (Kiarie, 2004; Tuncer, 2014). Göz şikayetleri arasında ise genellikle gözlerde yanma veya bulanık görme, iyi görememe, mide bulantısı, baş ağnısı, bir iş ya da etkinlik yaparken baş dönmesi, bulanık ya da çift görme, bir veya iki gözbebeğinin gri veya beyaz görünmesi, bir veya iki gözün çapraz, içe ya da dişa doğru dönmesi veya bir gözünün diğerinden farklı yöne hareket etmesi gibi şikayetler dikkati çekmektedir (Hallahan ve Kauffman, 2003; Smith, 2001).

Görme sorunlarının fark edilmesi doktor, ebeveyn ve diğer bakım verenler tarafından yapılmakta ve genellikle yaşamın ilk dört ayında fark edilerek tanı konabilmektedir. Ayrıca, görme problemleri okulda bazı görme fonksiyonlarındaki davranışlarını gözlemleyen öğretmenler tarafından da fark edilebilmektedir (Kiarie, 2004). Görme yetersizliği olan çocukların tanılanması farklı birtakım yollarla yapılmaktadır. Tanı konurken öncelikle çocuğun görme durumu hakkında ebeveynlerin gözlemleri, çocuğunda görme yetersizliği olduğundan şüphelenmelerine neden olan davranışları hakkında bilgi alınması, sonra da bozukluğun göz doktoru tarafından belirlenmesi önemlidir (Özgür, 2013). Ayrıca, görme yetersizliğini tanılamada çeşitli testler de kullanılmaktadır. Test seçimi ise çocuğun yaşına göre değişmektedir. Amerikan Pediatri Akademisi yeni doğandan üç yaşına kadar görme düzeyini 
belirlemede göz merceği durumu, gözleri ve göz kapaklarının kontrolü, göz merceğinin hareketlerini değerlendirme, kırmızı refle testi, kapatma testi ve ışığa refleks gibi testler ile değerlendirilmesi gerektiğini vurgulamaktadır (Berg vd. 2004).

Görme yetersizliği olan çocukların erken dönemden itibaren bilişsel, iletişim, bağımsız hareket ve yönelim, duyuları etkili kullanma, oyun ve sosyalleşme gibi birçok alanda desteklenmesi gerekmektedir (Başakçı Çalık vd. 2012; Kesiktaş, 2009). Tedavi edilmeyen ya da kalıcı olan görme sorunları çeşitli nedenlerle çocukların eğitim başarısını olumsuz yönde etkilemektedir. $\mathrm{Bu}$ çocuklar için uyarlanmış donanımla gören akranları ile birlikte benzer motor becerilere ve etkinliklere katılmalarının sağlanması çocukların başarı düzeylerini arttırmaktadır (Basch, 2011; Haibach, Wagner ve Lieberman, 2014). Bu çocukların bilişsel, dil, sosyal ve motor gelişimlerini de içeren gelişimini hızlandırmak için özel olarak düzenlenmiş öğrenme etkinlikleri ve rutinlerine sıklıkla katılması ile mümkündür. Bu nedenle erken dönemde erken müdahale çalışmaları önemli bir yere sahiptir (Spiker ve Wheeden, 1998).

Erken müdahale, gelişimsel gecikme ya da yetersizliği olan veya risk grubunda olan bebek ve küçük çocukların (36 aya kadar) ailelerine yönelik olarak geliştirilen programları ifade etmektedir. Erken müdahale, doğrudan, belli bir amaca yönelik bir yöntem çerçevesinde çocuğun içinde bulunduğu koşulları ya da kişilerle etkileşimini geliştirmeyi, güçlendirmeyi ya da değiştirmeyi hedeflemektedir (Howard, Williams ve Leper 2011). Erken müdahale, 3-5 yaş gelişimsel olarak desteklenmeye gereksinimi olan çocuklar için "erken çocukluk özel eğitimi veya okul öncesi özel eğitimi”, daha sonrasında ise "özel eğitim” adı altında devam eden bir süreçtir. Erken müdahalenin amacı, yetersizliği olan çocuklara yönelik uygun hizmetler sağlamak, gecikme ve yetersizlik düzeylerini en aza indirgeyebilmek, her bir çocuğun normal gelişimsel yapı taşlarına ulaşabilme sansını maksimum düzeye çıkarmak ve çocuklarının gelişimi için ailelerin olumlu şekilde yönlendirilmesine yardımcı olmaktır (Aytekin ve Bayhan, 2015). Erken müdahale çocuğun ve ailenin güçlü yönlerini ve gereksinimlerini kapsamlı bir şekilde değerlendirme ile başlar, uygun destek sağlayarak genişletir, çocuk geliştikçe hizmetlerini aktif bir şekilde izler ve faaliyetlerini yeniden değerlendirir. Sıklıkla, ebeveynler uygulamalara katılmaları için teşvik edilir ve destek müdahale faaliyetlerini evde de uygulayarak desteklerler (Mahoney, Boyce, FewellRamey ve Ramey, 1998).

Görme yetersizliği olan çocuklara yönelik erken çocukluk özel eğitimi müdahaleleri eve ve/veya merkeze dayalı yürütülmektedir. Ev merkezli çalışmalar çocuğu ve aileyi doğal ortamında görmeyi sağlamaktadır. Özellikle ailenin özelliklerinin anlaşılmasını ve bu koşullara uygun iş birliği etkinliklerinin geliştirilmesini sağlamak için önemlidir (Sönmez, 2013). 
Öğretmen görmeyen bebek ve ailesi ile düzenli zamanlarda ev ziyaretleri ile ebeveyni görme yetersizliğinin, çocuğunun gelişimi üzerindeki etkileri hakkında desteklemekte ve ebeveynlerin bebekleri ile etkili iletişim kurmalarında rehberlik etmektedir. Ayrıca, evin çocuğun ihtiyaçlarına göre düzenlenmesi için uygun fırsat sunmakta, ailenin eğitime etkin katılımını sağlamakta, bunun sonucunda ise aile olumsuz duygulardan uzaklaşarak çocuğun gelişimine daha fazla katkıda bulunmaktadır. Ayrıca, evde özel eğitim hizmetlerinin verilmesi aile için ulaşım sorununu da ortadan kaldırmaktadır. Merkeze dayalı programlar ise özel eğitim ve rehabilitasyon merkezleri, özel eğitim okulları ve kaynaştırma eğitimi şeklinde yürütülmektedir (Allen ve Cowdery, 2005; Davidson ve Harrison, 2000; Yıldırım Doğru, 2013). Görme yetersizliği olan çocuklar için öğrenmeye hazırlık, psiko-motor, öz bakım, günlük yaşam becerileri, bağımsız hareket becerileri, sosyal beceriler, Türkçe ve matematik modülleri uygulanmaktadır (MEB, 2013).

Görme yetersizliği olan çocukların gelişiminin desteklenmesi ve eğitimlerine aile üyelerinin de katılması önemli rol oynamaktadır. Anne görme yetersizliği olan/görmeyen bebeği ile etkileşime girmekte, duygusal bağ kurmakta güçlük çekebilmektedir. Görme yetersizliği olan/görmeyen çocuk ise ebeveyninin etkinliği başlatma ve sürdürmeye yönelik girişimlerini fark etmede güçlük yaşayabilmektedir. Çocuğun görme yetersizliğinin olması anneyle olan ortak dikkat, paylaşılan simgesel ve sözel iletişimlerinde sorun yaşamalarına neden olmaktadır. Aile çaresizlik duygularını aşmak ve çocuğunun gereksinimlerini karşılayabilmek için büyük desteğe gereksinim duymaktadır (Loots, Devisé ve Sermijn, 2003; Murdoch, 2002; Nergiz, 2013; Pinquart ve Pfeiffer, 2013). Eğitim çalışmalarında aileyi merkeze almak, aileye değer vererek ve aileye saygı duyarak yaklaşma, aile üyelerine karar vermelerinde gerekli tüm bilgileri sağlama, kaynak ve destek sağlama konusunda aileyi aktif kılma, ailenin istek ve taleplerine karşı esnek ve duyarlı olmayı sağlamaktadır. Ailenin desteklenmesi, ebeveyn-çocuk bağlanmasını teşvik etmekte ve çocuklarının bakımında ailenin etkili rol almasını sağlamaktadır (Aytekin, 2014; Murdoch, 2002).

Görme yetersizliğinin nedenlerine ve tanılanmasına yönelik birçok çalışmaya ulaşılsa da görme yetersizliği olan çocuklar ve ailelerin özellikleri, aile gereksinimleri ve almış oldukları eğitim türüne yönelik alanda yapılan yeterli çalışma olmadığı görülmüştür. Görme yetersizliği olan çocuk ve aileye yönelik olan bu bilgilerin erken müdahale, eğitim, rehabilitasyon hizmetlerinde yol gösterici olacağı ve ülkemizde bu konuda yapılmakta olan ve yapılaması planlanan mevzuatlara katkı sağlayacağı düşüncesiyle çalışma planlanmıştır. Bu çalışmada; görme yetersizliği olan çocuk ve ebeveynlerinin demografik bilgileri, görme yetersizliğinin fark 
edilmesi, tanılanması, görme yetersizliği olan çocukların eğitim bilgileri ve ebeveynlerinin aile destek çalışmalarına katılım durumları incelenmiştir.

\section{YÖNTEM}

\section{Araştırma Modeli}

$\mathrm{Bu}$ araştırma 2-10 yaşlar arasında görme yetersizliğine sahip olan çocukların demografik bilgileri, farkedilmesi, tanılanması, eğitimsel ve aldıkları aile destek çalışmalarının incelenmesi amacıyla planlanmıştır. Çalışma betimsel bir çalışmadır. Betimsel çalışmalar, ele alınan durumun olabildiğince tam ve dikkatli bir şekilde tanımlandığı araştırmalardır (Büyüköztürk, Çakmak, Akgün, Karadeniz ve Demirel, 2012).

\section{Çalışma Grubu ve Verilerin Toplanması}

Ankara il merkezinde 2-10 yaşlar arasında görme yetersizliğine sahip olan çocukların demografik bilgileri, görme yetersizliğinin farkedilmesi, tanılanması, eğitimsel ve aile destek özelliklerinin incelenmesi amacıyla yapılan bu çalışma 51 ebeveyn ile çalışma yürütülmüştür. Araştırmaya katılan ebeveynlerin eğitim ve yaş gruplarına bakıldığında; annelerin ve babaların 3'ü (\% 5,9) sadece okur yazar, annelerin 19'u (\% 37,3), babaların 7'si (\% 13,7) ilkokul, annelerin 6's1 (\% 11,8), babaların 7'si (\% 13,7) ortaokul, annelerin 11'i (\% 21,6), babaların 16'sı (\% 31,4) lise ve dengi, annelerin 4'ü (\% 7,8), babaların 5'i (\% 9,8) ön lisans, annelerin ve babaların 8'i (\% 15,7) üniversite, babaların 3'ü (\% 5,9) yüksek lisans eğitimine sahiptir. Annelerin 15'i (\% 29,4), babaların 8'i (\% 15,7) 21-30 yaşlar, annelerin 22'i (\% 43,1), babaların 23 ’ü (\% 45,1) 31-40 yaşlar, annelerin 13'ü (\% 25,5), babaların 17'si (\% 33,3) 41-50 yaşlar, annelerin ve babaların 1'i (\% 2) ise 51 yaş üzerindedir. Araştırmaya katılan çocukların cinsiyet, yaş, görme durumları incelendiğinde; çocukların 21'i (\% 41,2) kız, 30’u (\% 58,8) erkektir. Çocukların 8'i (\% 15,7) 2-4 yaşlar, 13'ü (\% 25,5) 5-7 yaşlar, 30’u (\% 58,8) ise 8-10 yaş grubundadır. Çocukların 51'i (\% 51) hiç görmezken, 25'i (\% 49) az görmekte, az gören 25 çocuğun ise 19'unun (\% 37,2) iki gözü de az görmekte, 4'ünün $(\%$ 7,8) tek gözü hiç görmezken diğer gözü tam görmekte, 1 'inin (\% 2) bir gözü normal, diğer gözü ise az görmekte, 1 (\% 2) çocuğun ise tek gözü hiç görmezken, diğer gözü az görmektedir.

Çalışma için Ankara ilinde bulunan özel eğitim merkezlerinin listeleri elde edilmiştir. Bu listede bulunan özel eğitim kurumlarından "görme yetersizliği programı" bulunan merkezler belirlenmiştir. Merkezlerle birebir görüşmeler yapılarak, çalışmaya katılmayı kabul eden Ankara ili Çankaya, Keçiören, Yenimahalle, Altındağ ilçelerinde bulunan on özel eğitim merkezi ile araştırma yürütülmüştür. On kurumda 2-10 yaş aralığında toplam 80 çocuğun 
olduğu belirlenmiştir. Kurumlara devam eden iki yaşın altında çocuk bulunmamaktadır. Özel eğitim merkezlerine bazı çocuklar servisle gelip gitmekte, bazı çocuklar ise ebeveynleri tarafından getirilmektedir. Ebeveynleri tarafından getirilen çocukların ders saatleri öğrenilerek, araştırmacı tarafından hazırlanan "Görme Yetersizliği Olan Çocukların Demografik, Tanılanma, Eğitimsel ve Aile Destek Bilgi Formu "nun görüşülerek uygulanması planlanmıştır. Form, kuruma gelen 20 ebeveynle görüşülerek uygulanmıştır, 10 ebeveyn ise çalışmaya katılmak istemediği için görüşmeyi kabul etmemiştir. Diğer ebeveynler ise kuruma gelmediği için formlar evlere gönderilmiştir. Ancak evlere gönderilen formlardan 31'i geri dönerken 19’u dönmemiştir.

\section{Veri Toplama Aracı}

Görme Yetersizliği Olan Çocukların Demografik, Tanılanma, Eğitimsel ve Aile Destek Bilgi Formu

Ankara il merkezinde 2-10 yaşlar arasında görme yetersizliğine sahip olan çocukların demografik, görme yetersizliğinin fark edilmesi ve tanılanması, eğitimsel ve aile destek özelliklerinin incelenmesi amacıyla yapılan bu çalışmada, araştırmacı tarafından 16 soruluk “Görme Yetersizliği Olan Çocukların Demografik, Tanılanma, Eğitimsel ve Aile Destek Bilgi Formu" hazırlanarak sekiz uzmandan görüş alınmıştır. Uzmanlardan üçü Çocuk Gelişimi alanında, üçü ise özel eğitim alanından akademisyen, iki uzman ise görme yetersizliği olan çocuklarla aktif çalışan görme engelliler öğretmenidir. Uzman görüşlerinden sonra düzeltmeler yapılarak formun anlaşılırlığını anlamak amacıyla beş aileye pilot çalışma yapılmıştır. Formun ilk bölümünde ebeveyne ve çocuğa ait demografik bilgiler (anne ve babanın eğitim durumu, yaş1 ve mesleği, çocuğun doğum tarihi, cinsiyeti, görme düzeyi, az görüyorsa hangi gözün ne kadar görebildiği, aile ve yakınlarda görme yetersizliğinin bulunma durumu, bulunuyorsa kimde olduğu), ikinci bölümde, görme yetersizliğinin fark edilme zaman1, nasıl fark edildiği, çocuğun görme yetersizliğinden şüphelenilmesine neden olan davranışları, tanıyı kim ya da hangi birimin koyduğu, tanının ne zaman konduğu, nedeni olarak aileye ne söylendiği gibi görme yetersizliğinin fark edilmesi ve tanılanmasına yönelik sorular sorulmuştur. Üçüncü bölümde, görme yetersizliği olan çocuğun devam ettiği eğitim kurumu/kurumları, eğitime başlama yaşı, özel eğitim hizmet türü ve eğitim modüllerine yönelik sorular sorulmuştur. Son bölümde ise, görme yetersizliğinin belirlenmesinden sonra aile eğitim çalışmalarının yapılma durumu, aile eğitim çalışmalarının türü (bireysel/grup) ve eğitimin kim tarafından verildiği, aile eğitim çalışmalarında hangi konular üzerinde durulduğu gibi sorular sorulmuştur. Ayrıca, formda sorulan sorularda görme yetersizliğinin nedenleri, görme yetersizliğinden şüphelenme 
ve doktora gitmeye neden olan çocuğun davranışları, çocuğun devam ettiği eğitim kurum/kurumları, eğitim modülleri, ebeveynlerin katıldıkları aile eğitim çalışmaları, bu eğitimleri veren uzmanlar ve aile eğitim çalışmalarında eğitim aldıkları aile eğitim konuları ile ilgili sorulan sorularda çalışmaya katılan ebeveynlerin birden fazla seçenek işaretleme firsatı sunulmuştur ve formda yazılan maddelerin dişında eklemek istedikleri bilgileri de eklemeleri istenmiştir.

\section{Verilerin Analizi}

2-10 yaşlar arasındaki görme yetersizliğine sahip olan çocuk ve ebeveynlerinin demografik bilgileri, görme yetersizliğinin fark edilmesi, tanılanması, eğitimsel ve aile destek özelliklerini incelenmek amacıyla yapılan çalışmada betimsel veri analizi kullanılmıştır. Verilerin analizi SPSS 22 programı kullanılarak yapılmıştır. Verilerin çözümlenmesinde yüzde, frekans ve $\mathrm{x}^{2}$ istatistikleri kullanılmıştır.

\section{BULGULAR}

Araştırmadan elde edilen bulgular görme yetersizliği olan çocuk ve ebeveynlerinin demografik bilgilerine ilişkin bulgular, görme yetersizliğinin fark edilmesi ve tanılanmasına ilişkin bulgular, görme yetersizliği olan çocukların eğitimlerine ilişkin bulgular ve görme yetersizliği olan çocukların aile destek bilgilerine ilişkin bulgular olmak üzere dört başlık altında sunulmuştur.

\section{Görme Yetersizliği Olan Çocuk ve Ebeveynlerinin Demografik Bilgilerine İlişkin Bulgular}

Araştırmaya katılan çocukların yaş, cinsiyet, görme düzeyi ve az gören çocukların göz durumu ile ilgili bilgiler Tablo 1'de verilmiştir.

Tablo 1. Görme yetersizliği olan çocukların demografik bilgilerine ait dağıllımı

\begin{tabular}{|c|c|c|c|}
\hline \multicolumn{2}{|c|}{ Çocuklara ait özellikler } & $f$ & $\%$ \\
\hline \multirow{3}{*}{ Cinsiyet } & K1z & 21 & 41,2 \\
\hline & Erkek & 30 & 58,8 \\
\hline & Toplam & 51 & 100,0 \\
\hline \multirow{4}{*}{ Yaş } & $2-4$ yaş & 8 & 15,7 \\
\hline & $5-7$ yaş & 13 & 25,5 \\
\hline & $8-10$ yaş & 30 & 58,8 \\
\hline & Toplam & 51 & 100,0 \\
\hline \multirow{3}{*}{ Görme düzeyi } & Hiç görmeyen & 26 & 51,0 \\
\hline & Az gören & 25 & 49,0 \\
\hline & Toplam & 51 & 100,0 \\
\hline \multirow{2}{*}{$\begin{array}{l}\text { Az gören gözün } \\
\text { durumu }\end{array}$} & İki gözünün de az gördüğü & 19 & 37,2 \\
\hline & Bir gözünün normal, diğer gözünün az gördüğü & 1 & 2,0 \\
\hline
\end{tabular}


Tek gözünün hiç görmediği, diğer gözünün tam gördügü

Tek gözünün hiç görmediği, diğer gözünün az gördüğ̈̈

Tablo 1'de araştırmaya katılan çocukların cinsiyet ve yaşları incelendiğinde, çocukların çoğunluğunun erkek olduğu, çocukların daha çok 8-10 yaşlar arasında olduğu görülmektedir. Çocukların görme düzeyleri incelendiğinde, çocukların yarısından fazlasının hiç görmediği belirlenmiştir. Az gören çocukların ise çoğunun iki gözünün de az gördüğü tespit edilmiştir.

Ebeveynlerin demografik özellikleri; ebeveynlerin eğitim düzeyi, yaşı ve mesleği olmak üzere üç grupta ele alınmıştır. Ebeveynlere ait demografik bilgiler Tablo 2'de sunulmuştur.

Tablo 2. Ebeveynlerin demografik bilgilerine ait dăğlımı

\begin{tabular}{|c|c|c|c|c|c|}
\hline \multirow{2}{*}{\multicolumn{2}{|c|}{ Ebeveynlere ait demografik bilgiler }} & \multicolumn{2}{|c|}{ Anne } & \multicolumn{2}{|c|}{ Baba } \\
\hline & & $f$ & $\%$ & $f$ & $\%$ \\
\hline \multirow{9}{*}{ Eğitim düzeyi } & Sadece okur-yazar & 3 & 5,9 & 3 & 5,9 \\
\hline & İlkokul & 19 & 37,3 & 7 & 13,7 \\
\hline & Ortaokul & 6 & 11,8 & 7 & 13,7 \\
\hline & Lise ve dengi & 11 & 21,6 & 16 & 31,4 \\
\hline & Ön lisans (2 y1llık) & 4 & 7,8 & 5 & 9,8 \\
\hline & Üniversite & 8 & 15,7 & 8 & 15,7 \\
\hline & Yüksek lisans ve üstü & - & - & 3 & 5,9 \\
\hline & Ebeveyn vefat etmiş & - & - & 2 & 3,9 \\
\hline & Toplam & 51 & 100,0 & 51 & 100,0 \\
\hline \multirow{6}{*}{ Yaş } & $21-30$ yaş & 15 & 29,4 & 8 & 15,7 \\
\hline & $31-40$ yaş & 22 & 43,1 & 23 & 45,1 \\
\hline & $41-50$ yaş & 13 & 25,5 & 17 & 33,3 \\
\hline & 51 yaş ve üstü & 1 & 2,0 & 1 & 2,0 \\
\hline & Ebeveyn vefat etmiş & - & - & 2 & 3,9 \\
\hline & Toplam & 51 & 100,0 & 51 & 100,0 \\
\hline \multirow{10}{*}{ Meslek } & Ev hanımı & 43 & 84,3 & - & - \\
\hline & İşsiz & - & - & 2 & 3,9 \\
\hline & Doktor/hemşire & 1 & 2,0 & 4 & 7,8 \\
\hline & İşçi & 1 & 2,0 & 18 & 35,3 \\
\hline & Memur & 5 & 9,8 & 10 & 19,6 \\
\hline & Savci/avukat & - & - & 2 & 3,9 \\
\hline & Serbest (kendine ait iş yeri var) & - & - & 11 & 21,6 \\
\hline & Emekli & 1 & 2,0 & 2 & 3,9 \\
\hline & Ebeveyn vefat etmiş & - & - & 2 & 3,9 \\
\hline & Toplam & 51 & 100,0 & 51 & 100,0 \\
\hline
\end{tabular}

Tablo 2 incelendiğinde araştırmaya katılan annelerinin çoğunluğunun ilkokul mezunu olduğu, bunu ise sırası ile lise ve dengi, üniversite, ortaokul ve ön lisans programlarının izlediği görülmektedir. Ayrıca annelerin üçünün sadece okur-yazar olduğu gözlenmektedir. Babaların eğitim durumu incelendiğinde ise, babaların çoğunluğunun lise ve dengi okuldan mezun olduğu, bunu ise sırsıyla üniversite, ilkokul ve ortaokul, ön lisans programı, yüksek lisans ve 
üstü izlediği görülmektedir. Babaların üçünün ise sadece okur-yazar, ikisinin de vefat ettiği görülmektedir. Ebeveynlerin yaşlarına göre dağılımı incelendiğinde, annelerin ve babaların çoğunun 31-40 yaşlar arasında olduğu görülmektedir. İki babanın ise vefat ettiği tespit edilmiştir. Ebeveynlerin mesleklerine bakıldığında, annelerin çoğunluğunun ev hanımı, babaların çoğunluğunun ise işçi veya memur olduğu görülmektedir.

\section{Görme Yetersizliğinin Fark Edilmesi ve Tanılanmasına İlişkin Bulgular}

Görme yetersizliği olan çocukların ailelerinde görme yetersizliğinin bulunma durumu, ailede görme yetersizliği bulunuyorsa kimde olduğu, çocuğun görme yetersizliğinin fark edilme zamanı ve durumu, görme yetersizliğinin teşhisini koyan birim/kişi ve tanılama zamanı ile ilgili bilgiler Tablo 3'de özetlenmiştir.

Tablo 3. Ebeveynlerin çocuklarının görme yetersizliğinin belirlenmesine ilişkin verdikleri bilgilere ilişkkin dağglımı

\begin{tabular}{|c|c|c|c|}
\hline \multicolumn{2}{|c|}{$\begin{array}{l}\text { Ebeveynlerin çocuklarının görme yetersizliğinin belirlenmesine ilişsin } \\
\text { verdikleri bilgiler }\end{array}$} & \multirow{2}{*}{$\frac{f}{7}$} & \multirow{2}{*}{$\begin{array}{c}\% \\
13,3\end{array}$} \\
\hline \multirow{3}{*}{$\begin{array}{l}\text { Ailede olma } \\
\text { durumu }\end{array}$} & Evet, var & & \\
\hline & Hayır, yok & 44 & 86,3 \\
\hline & Toplam & 51 & 100,0 \\
\hline \multirow{4}{*}{$\begin{array}{l}\text { Ailede görme } \\
\text { yetersizliği } \\
\text { bulunan yakın }\end{array}$} & Ailede ve yakınlarda yok & 44 & 86,3 \\
\hline & Kardeş & 2 & 3,9 \\
\hline & Yakın akraba (anneanne/babaanne/dede/hala/amca/teyze) & 5 & 9,8 \\
\hline & Toplam & 51 & 100,0 \\
\hline \multirow{8}{*}{$\begin{array}{l}\text { Fark edilme } \\
\text { zamanı }\end{array}$} & Doğuştan (hamilelik döneminden fark edildi) & 12 & 23,5 \\
\hline & $0-3$ aylarında & 17 & 33,3 \\
\hline & 4-6 aylarında & 10 & 19,6 \\
\hline & $7-12$ aylarında & 3 & 5,9 \\
\hline & 1-2 yaşlarında & 3 & 5,9 \\
\hline & 3-4 yaşlarında & 3 & 5,9 \\
\hline & 5 yaşından sonra & 3 & 5,9 \\
\hline & Toplam & 51 & 100,0 \\
\hline \multirow{4}{*}{$\begin{array}{l}\text { Fark edilme } \\
\text { durumu }\end{array}$} & Doktor söyledi & 23 & 45,1 \\
\hline & Davranışlarından fark ettim & 22 & 43,1 \\
\hline & Genel kontroller sirasında ortaya çıktı & 6 & 11,8 \\
\hline & Toplam & 51 & 100,0 \\
\hline \multirow{4}{*}{$\begin{array}{l}\text { Teşhis koyan } \\
\text { hastane bölümü }\end{array}$} & Kadın Doğum & 4 & 7,8 \\
\hline & Göz Doktoru & 45 & 88,2 \\
\hline & Çocuk Doktoru & 2 & 3,9 \\
\hline & Toplam & 51 & 100,0 \\
\hline \multirow{8}{*}{$\begin{array}{l}\text { Tanilanma } \\
\text { zaman1 }\end{array}$} & Doğuştan & 11 & 21,6 \\
\hline & $0-3$ aylik & 13 & 25,5 \\
\hline & 4-6 aylik & 11 & 21,6 \\
\hline & $7-12$ aylik & 7 & 13,7 \\
\hline & 1-2 yaşlarında & 3 & 5,9 \\
\hline & 3-4 yaşlarında & 2 & 3,9 \\
\hline & 5 yaşından sonra & 4 & 7,8 \\
\hline & Toplam & 51 & 100,0 \\
\hline
\end{tabular}


Tablo 3 incelendiğinde görme yetersizliği olan çocukların çoğunda aile ya da yakınlarında görme yetersizliği bulunmamaktadır. Ailesinde/yakınlarında görme yetersizliği bulunan kişilerin ise daha çok anneanne/babaanne/dede/hala/amca/teyze gibi yakın akrabalarında olduğu dikkati çekmektedir. Görme yetersizliğinin fark edilme zamanı incelendiğinde, çocukların çoğunun 0-3 aylar arasında, doktorun söylemesiyle fark edildiği ve aynı dönemde tanılandığı, teşhisi ise daha çok göz doktorunun koyduğunu belirlenmiştir.

Görme yetersizliği olan çocukların görme düzeyi ile çocuğun görme yetersizliğinin fark edilme zamanı ve tanılama zamanı arasındaki ilişkiye ilişkin bilgiler Tablo 4'de özetlenmiştir.

Tablo 4. Görme yetersizliği olan çocukların görme düzeyi ile görme yetersizliğinin fark edilme zamanı arasındaki ve görme düzeyi ile görme yetersizliğinin tanılama zamanı arasındaki iliş̧kiye iliş̧kin dağılımı

Fark edilme zamanı (F.Z.)

\begin{tabular}{|c|c|c|c|c|c|c|c|c|c|c|c|}
\hline \multicolumn{2}{|l|}{$\begin{array}{c}\text { Görme Düzeyi } \\
\text { (G.D.) }\end{array}$} & Doğuştan & 0-3 Ay & $\begin{array}{l}4-6 \\
\text { Ay }\end{array}$ & $\begin{array}{c}7-12 \\
\text { Ay }\end{array}$ & $\begin{array}{l}1-2 \\
\text { Yas }\end{array}$ & $\begin{array}{l}3-4 \\
\text { Yas }\end{array}$ & $\begin{array}{c}5 \text { Yaş } \\
+\end{array}$ & Toplam & $x^{2}$ & $\mathrm{p}$ \\
\hline Görmeyen & $\mathrm{n}$ & 8 & 14 & 1 & 0 & 0 & 1 & 2 & 26 & & \\
\hline G.D.*F.Z. & $\mathrm{f}$ & 30,8 & 53,8 & 3,8 & 0,0 & 0,0 & 3,8 & 7,7 & 100,0 & & \\
\hline Az Gören & $\mathrm{n}$ & 4 & 3 & 9 & 3 & 3 & 2 & 1 & 25 & & \\
\hline G.D. *F.Z & $\mathrm{f}$ & 16,0 & 12,0 & 36,0 & 12,0 & 12,0 & 8,0 & 4,0 & 100,0 & 21,506 & ,001 \\
\hline Toplam & $\mathrm{n}$ & 12 & 17 & 10 & 3 & 3 & 3 & 3 & 51 & & \\
\hline \multirow[t]{3}{*}{ G.D.* F.Z. } & $\mathrm{f}$ & 23,5 & 33,3 & 19,6 & 5,9 & 5,9 & 5,9 & 5,9 & 100,0 & & \\
\hline & & \multicolumn{7}{|c|}{ Tanılanma zamanı (T.Z.) } & Toplam & $x^{2}$ & $p$ \\
\hline & & Doğuştan & $0-3$ Ay & $\begin{array}{l}4-6 \\
\text { Ay }\end{array}$ & $\begin{array}{c}7-12 \\
\text { Ay }\end{array}$ & $\begin{array}{l}1-2 \\
\text { Yaş }\end{array}$ & $\begin{array}{l}3-4 \\
\text { Yaş }\end{array}$ & $\begin{array}{c}5 \text { Yaş } \\
+\end{array}$ & & & \\
\hline Görmeyen & $\mathrm{n}$ & 8 & 11 & 3 & 2 & 0 & 0 & 2 & 26 & & \\
\hline G.D.*T.Z. & $\mathrm{f}$ & 30,8 & 42,3 & 11,5 & 7,7 & 0,0 & 0,0 & 7,7 & 100,0 & & \\
\hline Az Gören & $\mathrm{n}$ & 3 & 2 & 8 & 5 & 3 & 2 & 2 & 25 & & \\
\hline G.D.*T.Z. & $\mathrm{f}$ & 12,0 & 8,0 & 32,0 & 20,0 & 12,0 & 8,0 & 8,0 & 100,0 & 17,049 & ,009 \\
\hline Toplam & $\mathrm{n}$ & 11 & 13 & 11 & 7 & 3 & 2 & 4 & 51 & & \\
\hline G.D.*T.Z. & $\mathrm{f}$ & 21,6 & 25,5 & 21,6 & 13,7 & 5,9 & 3,9 & 7,8 & 100,0 & & \\
\hline
\end{tabular}

$\mathbf{p}<.05$ (G.D. Görme düzeyi, F.Z. Fark edilme zamanı, T.Z. Tanılanma zamanl)

Tablo 4'de görüldüğü gibi görme yetersizliği olan çocukların görme düzeyleri ile fark edilme zamanları arasında istatistiksel olarak anlamlı bir ilişki olduğu dikkati çekmektedir $\left(x^{2}: 21,506\right.$, p: ,001). Görmeyen çocukların çoğunluğu 0-3 aylar arasında fark edilirken, az gören çocukların 4-6 aylar arasında yoğunluk kazandığ 1 görülmektedir. Yani görmeyen çocuklar daha erken dönemde fark edilmektedir. Çocukların görme düzeyi ile tanılanma zamanı arasındaki ilişki 
incelendiğinde ise fark edilme zamanına ilişkin sonuçlarla paralellik gösterdiği görülmektedir. Görme yetersizliği olan çocukların görme düzeyleri ile tanılanma zamanları arasında istatistiksel olarak anlamlı bir ilişki olduğu $\left(\mathrm{x}^{2}: 17,049\right.$, p: ,009), görmeyen çocukların tanılanmasında 0-3 aylar arasında yoğunluk dikkati çekerken, az gören çocukların 4-12 aylar arasında olduğu görülmektedir. Bu sonuç da görmeyen çocukların daha erken dönemde tanılandığını göstermektedir. Tablo da görüldüğü gibi görme yetersizliği olan çocukların erken dönemde fark edilerek tanılanabildiği, özellikle görmeyen çocukların az görenlere göre daha erken dönemde fark edildiği, dolayısı ile erken dönemde tanılamanın yapılabildiği belirlenmiştir.

Ebeveynlere sorulan "Çocuğunuzun görme yetersizliğinin nedeni konusunda size ne söylendi?" sorusunda ebeveynlere 12 farklı neden sunulmuş ve birden fazla işaretleme yapmalarına izin verilmiştir. Ayrıca bu maddeler dışında farklı söylenen bir neden olup olmadığı, eğer varsa ne söylendiğini yazmaları istenmiştir. Ebeveynlere birden fazla seçenek işaretleme firsatı sunulduğu için tabloda toplamlar alınmamıştır. Sonuçlar Tablo 5'de özetlenmiştir.

Tablo 5. Ebeveynlere çocuklarının görme yetersizliği yaşaması konusunda belirtilen nedenlere yönelik yanıtlarına ilişkin dağılımı

\begin{tabular}{lcc}
\hline $\begin{array}{l}\text { Ebeveynlerin “Çocuğunuzun görme yetersizliğinin nedeni konusunda } \\
\text { size ne dendi?" sorusuna verdikleri yanıtlar }\end{array}$ & $\boldsymbol{f}$ & $\boldsymbol{\%}$ \\
\hline Hiçbir açıklama yapılmadı & 19 & 37,3 \\
Kalıtım & 7 & 13,7 \\
Annenin hamilelik döneminde geçirdiği hastalıklar ve enfeksiyonlar & 6 & 11,8 \\
Çocuğumun erken dönemde geçirdiği düşme ve zedelenmeler & 1 & 2,0 \\
Kuvözde yatarken fazla oksijenin verilmesi & 6 & 11,8 \\
Çocukluk döneminde geçirilen hastalıklar & 5 & 9,8 \\
Çocuğumun geçirdiği ateşli hastalıklar ve zehirlenmeler & 1 & 2,0 \\
Çocuğumun beynindeki tümör & 3 & 5,9 \\
Çocuğumda gelişen göz tansiyonu & 2 & 3,9 \\
Çocuğumun doğum sırasında oksijensiz kalması & 1 & 2,0 \\
\hline
\end{tabular}

Tablo 5 incelendiğinde, araştırmaya katılan çocukların görme yetersizliğinin nedeni konusunda ebeveynlerin verdiği yanıtlar arasında en fazla "hiçbir açıklama yapılmadığı" yanıtı dikkati çekmektedir. Açıklama yapılan yanıtlar arasında ise en fazla kalıtım, bunu ise annenin hamilelik döneminde geçirdiği hastalıklar ve enfeksiyonlar, kuvözde yatarken fazla oksijenin verilmesi ve çocukluk döneminde geçirilen hastalıklar yer almaktadır.

Ebeveynlere sorulan "Çocuğunuzda görme yetersizliğinden şüphelenmenize ve doktora gitmenize neden olan davranışları nelerdi?" sorusunda ebeveynlere 17 farklı seçenek sunulmuş ve bu seçeneklerden farklı davranış/belirti varsa eklemeleri istenmiştir. Ebeveynlerin bu soruya 
birden fazla işaretleme yapılmasına izin verilmiş ve bu nedenle tabloda toplamlar alınmamıştır.

Sonuçlar Tablo 6'da özetlenmiştir.

Tablo 6. Ebeveynlerin çocuklarının görme yetersizliğine sahip olduğu fikrini veren davranışlar/belirtilere yönelik yanıtlarına ilişskin dă̆ıllımı

\begin{tabular}{|c|c|c|}
\hline $\begin{array}{l}\text { Ebeveynlerin "Çocuğunuzda görme yetersizliğinden şüphelenmenize } \\
\text { ve doktora gitmenize neden olan davranışları/belirtileri nelerdi?" } \\
\text { sorusuna verdikleri yanıtlar }\end{array}$ & $f$ & $\%$ \\
\hline Hamilelik döneminde ayrıntılı ultrasonda belli oldu & 11 & 21,6 \\
\hline Herhangi bir davranışından şüphelenmedim & 7 & 13,7 \\
\hline Doktor söyledi & 11 & 21,6 \\
\hline \multicolumn{3}{|l|}{ Davranışlar } \\
\hline Sürekli ileri-geri sallanma & 7 & 13,7 \\
\hline Etrafında daireler çizerek dönme & 3 & 5,9 \\
\hline S1klıkla parlak 1şı̆̆a bakma & 8 & 15,7 \\
\hline Gözlerini aşırı şekilde ovuşturma & 11 & 21,6 \\
\hline Gözlerinden birini kapatmaya çalışma & 4 & 7,8 \\
\hline Bir şeye bakarken ona doğru çok eğilme & 3 & 5,9 \\
\hline $\begin{array}{l}\text { Oyuncağına bakma, resim çizme ya da kitaba bakma gibi etkinliklerde } \\
\text { nesneyi gözlerine çok yaklaştırma, nesne, oyuncak ya da yazılı materyali } \\
\text { gözlerine yakın tutmaya çalışma }\end{array}$ & 9 & 17,6 \\
\hline Uzaktaki nesneleri açık net bir şekilde tarif edememe & 5 & 9,8 \\
\hline \multicolumn{3}{|l|}{ Belirtiler } \\
\hline Gözlerini olağandan fazla kırpıştırma & 2 & 3,9 \\
\hline Gözlerini kısma, kaşlarını çatma & 2 & 3,9 \\
\hline Gözlerinde sık sık yanma, yaşarma ve kaşıntı & 5 & 9,8 \\
\hline $\begin{array}{l}\text { Baş dönmesi, baş ağrısı, yakından bakmayı gerektiren işlerden sonra } \\
\text { mide bulantısı, bulanık ve çift görme }\end{array}$ & 1 & 2,0 \\
\hline Göz kapağında sıklıkla şişlik ya da gözde çapaklanma & 1 & 2,0 \\
\hline
\end{tabular}

Tablo 6'da görüldüğü gibi ebeveynlerin çocuklarının görme yetersizliğine sahip olduğunu fark etmelerini sağlayan belirtilerden en fazla hamilelik döneminde ayrıntılı ultrasonda belli olması ve doktorun söylemesiyle ortaya çıktığı belirlenmiştir. Ebeveynin çocuklarında görme yetersizliğinden şüphelenmelerine neden olan davranışları arasında en fazla çocuklarının aşırı şekilde gözlerini ovuşturma, en az ise çocuklarının etrafında daireler çizerek dönme ve bir şeye bakarken ona doğru çok eğilme davranışlarının olduğu dikkati çekmektedir. Ebeveynlerin çocuklarının görme yetersizliğine sahip olduğunu fark etmelerini sağlayan belirtiler arasında ise en fazla çocuklarının gözlerinde yanma, yaşarma ve kaşıntı olduğu belirlenmiştir. Ebeveynlerin yedisi ise çocuklarında görme yetersizliği olduğunu onların herhangi bir davranışından şüphelenmediğini belirlenmişlerdir. 


\section{Görme Yetersizliği Olan Çocukların Eğitimlerine İlişkin Bulgular}

Bu bölümde, ebeveynlerden çocukların eğitim aldıkları kurumu/kurumları, eğitime başlama yaş, özel eğitim hizmet türü ve çocuğun devam ettiği özel eğitim modülleri hakkında bilgi alınmıştır.

Araştırmaya katılan çocukların devam ettiği eğitim kurumu/kurumlarına yönelik bilgiler Tablo 7'de özetlenmiştir. Bazı görme yetersizliği olan çocuklar birden fazla eğitim kurumuna devam ettiği için ebeveynlerin birden fazla seçenek işaretlemesine izin verilmiştir. Bu nedenle tabloda toplamlar yer almamaktadir.

Tablo 7. Araştırmaya katılan görme yetersizliğine sahip çocukların devam ettiği eğitim kurumlarına göre dağılımı

\begin{tabular}{lcc}
\hline Çocukların devam ettiği eğitim kurumları & $\boldsymbol{f}$ & \% \\
\hline Özel eğitim ve rehabilitasyon merkezi & 17 & 33,3 \\
Özel eğitim okulu & 19 & 37,3 \\
Resmi ilköğretim okulunun anaokulu (Kaynaştırma eğitimi) & 14 & 27,5 \\
Özel ilköğretim okulunun ya da kolejin anaokulu (Kaynaştırma eğitimi) & 16 & 31,4 \\
Görme engelliler ilköğretim okulu & 21 & 41,2 \\
Evde destek & 12 & 23,5 \\
\hline
\end{tabular}

Tablo 7'de görüldüğ̈̈ gibi görme yetersizliği olan çocukların en fazla görme engelliler ilköğretim okuluna devam ettiği, en az ise evde destek aldıkları belirlenmiştir.

Araştırmaya katılan görme yetersizliği olan çocukların özel eğitim ve rehabilitasyon desteği almaya başlama yaşı ve yararlandıkları özel eğitim hizmet türlerine ilişkin bilgiler Tablo 8'de özetlenmiştir.

Tablo 8. Görme yetersizliği olan çocukların ĕgitime başlama ve yararlandıkları özel ĕgitim hizmet türlerine ilişkin bilgilerin dağılımı

\begin{tabular}{llrr}
\hline $\begin{array}{l}\text { Görme yetersizliği olan çocukların eğitime başlama ve hizmet türlerine } \\
\text { ilişkin bilgiler }\end{array}$ & $\boldsymbol{f}$ & $\boldsymbol{\%}$ \\
\hline & 0-1 yaşlar & 19 & 37,3 \\
& 2-3 yaşlar & 17 & 33,3 \\
Özel eğitim ve rehabilitasyon desteği & 4-5 yaşlar & 6 & 11,8 \\
almaya başlama yaşı & 6-7 yaşlar & 7 & 13,7 \\
& 8-9 yaşlar & 2 & 3,9 \\
\cline { 2 - 5 } & Toplam & 51 & 100,0 \\
\hline \multirow{4}{*}{ Özel eğitim hizmet türü } & Bireysel eğitim & 22 & 43,1 \\
& Grup eğitimi & 1 & 2,0 \\
& Bireysel ve grup eğitimi & 28 & 54,9 \\
\cline { 2 - 4 } & Toplam & 51 & 100,0 \\
\hline
\end{tabular}

Tablo 8 incelendiğinde görme yetersizliği olan çocukların çoğunluğunun 0-1 yaşlarından itibaren özel eğitim ve rehabilitasyon desteği almaya başladığı görülmektedir. Görme yetersizliği olan çocukların çoğunluğunun erken dönemde eğitime başladığı görülmektedir. 
Çocukların devam ettiği eğitim kurumlarındaki hizmet türü incelendiğinde ise çoğunun hem bireysel eğitimi hem de grup eğitiminden yararlandığı belirlenmiştir.

Araştırmaya katılan ebeveynlerin çocuklarının devam ettiği özel eğitim modüllerini belirtmeleri istenen soruda katılımcılar birden fazla seçeneği işaretleyebilmişlerdir. Bu nedenle tabloda toplamlar verilmemiştir. Sonuçlar Tablo 9'da özetlenmiştir.

Tablo 9. Görme yetersizliği olan çocukların devam ettiği ĕgitim modüllerine ilişskin dă̆ıllımı

\begin{tabular}{lcc}
\hline Görme yetersizliği olan çocukların devam ettiği eğitim modülleri & $\boldsymbol{f}$ & $\boldsymbol{\%}$ \\
\hline Öğrenmeye Hazırlık Modülü & 17 & 33,3 \\
Psiko-Motor Beceriler Modülü & 19 & 37,3 \\
Öz Bakım Beceriler Modülü & 14 & 27,5 \\
Günlük Yaşam Beceriler Modülü & 16 & 31,4 \\
Bağımsız Hareket Becerileri Modülü & 21 & 41,2 \\
Sosyal Beceriler Modülü & 13 & 25,5 \\
Türkçe Modülü & 29 & 56,9 \\
Matematik Modülü & 29 & 56,9 \\
\hline
\end{tabular}

Tablo 9'a bakıldığında görme yetersizliği olan çocukların en fazla Türkçe ve Matematik Modüllerine devam ettikleri tespit edilmiştir. Araştırmaya katılan çocukların çoğu ilköğretim okuluna devam ettiği için en fazla Türkçe ve Matematik Modüllerine devam ettiği düşünülmektedir. Daha sonra en fazla devam edilen eğitim modülleri sırasıyla Bağımsız Hareket Becerileri Modülü, Psiko-Motor Beceriler Modülü, Öğrenmeye Hazırlık Modülü ve Günlük Yaşam Beceriler Modülü ve Sosyal Beceriler Modülüdür.

\section{Görme Yetersizliği Olan Çocukların Aile Destek Bilgilerine İlișkin Bulgular}

$\mathrm{Bu}$ bölümde araştırmaya katılan ebeveynlerin aile eğitim çalışmalarına katılma durumu, katıldıkları aile eğitim çalışmalarının türü, aile eğitimini aldıkları uzmanlar ve aile eğitim konuları hakkında bilgi alınmıştır.

Araştırmaya katılan ebeveynlerin hemen hemen hepsinin aile eğitim çalışmalarına katıldığı belirlenmiştir. Aile eğitim çalışmalarına katılan ebeveynlerin aldıkları aile eğitim desteği türüne yönelik bilgiler Tablo 10’ da özetlenmiştir. Ebeveynlerin birden fazla seçeneği işaretlemelerine izin verildiği için tabloda toplamlar verilmemiştir.

Tablo 10. Çocuğunda görme yetersizliği belirlendiğinde ebeveynin katıldĭ̆ı aile eğitim çalışmalarına ilişskin bilgilerin dă̆ılımı

\begin{tabular}{lrc}
\hline Ebeveynin katıldığı aile eğitim çalışmaları & $\boldsymbol{f}$ & $\boldsymbol{\%}$ \\
\hline Doktor tarafından verilen eğitim & 12 & 23,5 \\
Bireysel aile eğitimi & 29 & 56,9 \\
Grup aile eğitimi & 10 & 19,6 \\
Seminerler & 3 & 5,9 \\
\hline
\end{tabular}


Tablo 10 incelendiğinde ebeveynler çocuklarında görme yetersizliği olduğunu öğrendikten sonra en fazla çocuklarının başladığı özel eğitim ve rehabilitasyon merkezi tarafından verilen bireysel aile eğitim çalışmalarına katıldığı, bunu ise doktor tarafından verilen eğitim ve çocuğun başladığı özel eğitim ve rehabilitasyon merkezinde düzenlenen grup aile eğitim çalışmaları izlemiştir. Ebeveynlerin en az katıldığı aile eğitim çalışmaları ise bu konuda düzenlenen seminerler olmuştur.

Aile eğitim çalışmalarının kimler tarafından verildiğine dair bilgi Tablo 11'de özetlenmiştir. Ebeveynlerin birden fazla seçeneği işaretlemelerine izin verildiği için tabloda toplamlar verilmemiştir.

Tablo 11. Ebeveynlerin aile ĕgitim çalışmalarını aldı̆̆ı uzmanlara göre dağılımı

\begin{tabular}{lcc}
\hline Ebeveynleri aile eğitim çalışmalarını yapan uzman & $\boldsymbol{f}$ & $\boldsymbol{\%}$ \\
\hline Doktor & 10 & 19,6 \\
Görme engelliler öğretmeni & 26 & 51,0 \\
Psikolojik danışman & 11 & 21,6 \\
Profesyoneller & 9 & 17,6 \\
\hline
\end{tabular}

Tablo 11'de görüldügü gibi ebeveynler çocuklarında görme yetersizliğinin olduğunu öğrendikten sonra aile eğitim çalışmalarını daha çok çocuklarının devam ettiği merkezdeki görme engelliler öğretmenlerinden almıştır. Bazı aileler ise birbirine yakın oranlarda doktor ve psikolojik danışman tarafından, en az ise alanda çalışan profesyoneller tarafından destek aldığ dikkati çekmektedir.

Ebeveynlerin aile eğitim çalışmalarında bilgi aldıkları konular sıralanarak, bu konular dışında farklı konularda eğitim almaları durumunda eğitim aldıkları konuları yazmaları istenmiştir. Ayrıca ebeveynlerin birden fazla seçeneği işaretlemelerine izin verildiği için tabloda toplamlar verilmemiştir. Sonuçlar ise Tablo 12'de özetlenmiştir.

Tablo 12. Ebeveynlerin aile eğitim çalışmalarında eğitim aldıkları konulara iliş̧kin dağıllımları

\begin{tabular}{lcc}
\hline Ebeveynlerin aile eğitim çalışmalarını aldıkları konular & $\boldsymbol{f}$ & $\mathbf{\%}$ \\
\hline Çocuğumun gelişimini nasıl desteklemeliyim? & 24 & 47,1 \\
Çocuğumun rahat hareket edebilmesi için ev ortamını nasıl düzenlemeliyim? & 20 & 39,2 \\
Çocuğumun işitme, koklama, dokunma gibi duyularını nasıl geliştirebilirim? & 17 & 33,3 \\
Çocuğumla nasıl oyun oynamalıyım? & 20 & 39,2 \\
Çocuğuma ne tür oyuncaklar alabilirim ya da hazırlayabilirim? & 19 & 37,3 \\
Çocuğumla nasıl konuşabilirim? & 20 & 39,2 \\
Çocuğumla nasıl iletişim kurabilirim? & 26 & 51,0 \\
Çocuğuma nasıl davranmalıyım? & 30 & 58,8 \\
\hline
\end{tabular}

Tablo 12'de görüldüğü ebeveynlerin çoğu "Çocuğuma nasıl davranmalıyım?”, "Çocuğumla nasıl iletişim kurabilirim?” ve "Çocuğumun gelişimini nasıl desteklemeliyim?" konulu aile eğitim çalışmalarında katıldıklarını belirtmişlerdir. Destek alınan aynı oranlarda belirlenen 
diğer aile eğitim konuları ise "çocuğumun rahat hareket edebilmesi için ev ortamını nasıl düzenlemeliyim? çocuğumla nasıl oyun oynamalıyım? ve çocuğumla nasıl konuşabilirim?, konuları olmuştur. Ebeveynler sıralanan konular dışında farklı bir konuda eğitim almamıştır.

\section{SONUÇ ve TARTIŞMA}

2-10 yaşlar arasında görme yetersizliği olan çocukların demografik, görme yetersizliklerinin fark edilmesi ve tanılanması, eğitimleri ve aile destek çalışmalarını inceleyen çalışmada elde edilen bulgular tartışma bölümünde de aynı başlıklar altında alınmıştır.

Çocukların ve ebeveynlerin demografik özellikleri içerisinde, çocuğun cinsiyeti, yaşı, görme düzeyi, az gören çocuklarda gören gözünün durumu, ebeveynlerin ise ebeveynin eğitim düzeyi, yaşı ve mesleği şeklinde ele alınmıştır. Araştırmaya katılan görme yetersizliği olan çocukların demografik özellikleri incelendiğinde, çalışmaya katılan çocukların çoğunun erkek olduğu, yaşları açısından küçük yaşlardaki çocukların dağılımlarında benzerlik görülürken, büyük kısmının 10 yaşlarında olduğu dikkati çekmektedir. Araştırmaya katılan çocukların yarısından çoğunun hiç görmediği, az gören çocukların ise \%80 gibi büyük bir kısmının her iki gözünün de az gördüğü belirlenmiştir. Ebeveynlerin demografik özellikleri incelendiğinde ise annelerinin çoğunun ilkokul, babaların ise lise ve dengi okuldan mezun oldukları belirlenmiştir. Annelerin ve babaların genelinin 31-40 yaşlar arasında olduğu, annelerin çoğunun ev hanımı, babaların çoğunun ise işçi veya memur olduğu saptanmıştır.

Görme yetersizliğinin fark edilmesi ve tanılanmasına ilişkin bulgular arasında ebeveynlerin görme yetersizliğinin belirlenmesine ilişkin aldıkları bilgiler, görme yetersizliğinin nedeni, görme yetersizliğinden şüphelenmelerine ve doktora gitmelerine neden olan davranış/belirtilere yönelik yanıtları incelenmiştir. Görme yetersizliğinin belirlenmesine ilişkin bilgiler arasında; görme yetersizliğinin ailede bulunma durumu, bulunuyorsa kimde olduğu, görme yetersizliğinin fark edilme zamanı ve fark edilme durumu, görme yetersizliğinin teşhisi koyan birim ya da kişi ve tanılama zamanı ile ilgili bilgiler incelenmiştir. Ebeveynlerin görme yetersizliğinin belirlenmesine ilişkin verdiği bilgiler arasında ailelerin yarısından fazlasında bu yetersizliğin bulunmadığı, yakınları arasında görme yetersizliği bulunan ailelerde ise daha çok anneanne, babaanne, dede, hala, amca, teyze gibi akrabalarında olduğunu belirtmişlerdir. Görme yetersizliği, çocukların çoğunda 0-3 aylar gibi erken dönemde doktor tarafından fark edildiği, teşhisini ise göz doktorlarının koyduğu, fark edildiği dönemde ise tanının da konduğu görülmüştür. Görüldüğü gibi görme yetersizliği olan çocukların erken dönemde fark edilerek tanılanabildiği, özellikle görmeyen çocukların az görenlere göre daha erken dönemde fark edilerek, erken dönemde tanı konmuştur. Çalışmaya katılan çocuklardan hiç görmeyen 
çocukların 0-3 aylar, az gören çocukların ise 4-6 aylar arasında fark edildiği görülmektedir. Bununla da paralel olarak çocukların aynı aylarda tanıları konmuştur. Bu bebeklerin hamilelik döneminde ayrıntılı ultrasonda belli olması ve doktorun söylemesi bu bebeklerin daha erken dönemde fark edilmesi ve tanılanmasını sağlamıştır. Çocukların erken dönemde fark edilip tanılanmasına rağmen çalışmada ulaşılan ve eğitime başlayan çocukların 2-10 yaşlar aralığında olduğu dikkati çekmektedir. Bu sonuç da bu çocukların erken dönemde tanılansa da bir eğitim kurumunda eğitim almaya başlamalarının daha sonraki yıllarda başladığını göstermekte ve bu çocukların daha çok evde desteklendiğini düşündürmektedir. Çalışmanın yapıldığı eğitim kurumlarına en küçük yaş grupları sorulduğunda ise iki yaş altında ve bebek grubuna rastlanmamıştır. Solebo ve Rahi (2014), erken dönemde görme yetersizliğini belirlemede ve çocukluktaki etkisini en aza indirgemek için erken teşhis ve multidisipliner yönetimde çocuk hekimlerinin ve pediatri uzmanlarının önemli bir rol aldığını belirtmişlerdir.

Ebeveynlere görme yetersizliğinin nedeni konusunda verilen bilgiler sorulduğunda, alınan yanıtlar arasında kalıtım, annenin hamilelik döneminde geçirdiği hastalıklar ve enfeksiyonlar, kuvözde yatarken bebeğe fazla oksijenin verilmesi ve çocukluk döneminde geçirilen hastalıklar önemli bir yer almıştır. Ayrıca, ebeveynlerin önemli bir çoğunluğu da kendilerine herhangi bir açıklama yapılmadığını belirtmişlerdir. Eckstein, Foster ve Gilbert (1995), görmeyen ve ileri derecede görme yetersizliği olan çocuklarda görme yetersizliğinin nedenlerini belirlemek amacıyla yaptıkları çalışmada, körlügüun sıklıkla görülme nedenleri arasında retina, lens ve optik sinirlerde görülen kalıtsal hastalıklar ve akraba evliliği olduğu, A vitamini eksikliğinin nadiren gözlenen bir neden olduğunu saptamışlardır. Gilbert ve Foster (2001) ise çocuklarda körlüğün başlıca nedenlerinin büyük ölçüde ülkenin sosyo-ekonomik düzeyi, temel sağlık hizmetleri ve göz sağlığı hizmetlerinin mevcudiyeti ile ilişkili olduğunu bölgeden bölgeye büyük farklılıklar gösterdiğini belirlemişlerdir. Buna göre yüksek gelirli ülkelerde baskın oranda optik sinir lezyonları ve daha yüksek görme yolları körlüğün nedeni arasında yer alırken, düşük gelirli ülkelerde kızamık, korneada görülen problemler, A vitamini eksikliği, zararlı yanlış göz tedavi yöntemlerinin kullanımı ve göz iltihabı daha yaygın olarak gözlenmiştir. Orta gelir düzeyindeki ülkelerde ise prematüre retinopati önemli bir nedendir. Gogate, Gilbert ve Zin (2011) ise kalıtım, doğuştan göz yokluğu (anoftalmi), gözlerin normalden küçük olması (mikroftalmi), kolobom (göz küresinde veya bu organın herhangi bir kısmında mevcut olan konjenital fsitü), doğuştan katarakt ve infantil glokomun görme yetersizliğine neden olduğu belirlenmiştir. Etiyopya'da yapılan bir çalışmada erken dönemde görülen körlük ve ciddi görme yetersizliğinin başlıca nedenleri arasında ise A vitamini eksikliği ve kızamık olduğunu 
belirlemişlerdir (Kello ve Gilbert, 2003). Muhit, Shah, Gilbert ve Foster (2007) ise Bangladeş'te çocukluk çağı görme bozukluğunun temel nedeni olarak A vitamini eksikliği olduğunu belirlemişlerdir. Yapılan çalışmalarda da görüldüğü gibi görme yetersizliğinin nedenlerine yönelik birçok neden belirlense de bu nedenler arasında en önemli nedenler kalıtım ve A vitamini eksikliğinin olduğu görülmektedir. Bu çalışmada da görme yetersizliğinin nedenleri arasında ilk sırayı kalıtım almıştır.

Ebeveynlerin görme yetersizliğinden şüphelenmelerine ve doktora gitmelerine neden olan davranışlar/belirtilere yönelik verdikleri yanıtlar incelendiğinde, ebeveynlerin en fazla çocuklarının gözlerini aşırı şekilde ovuşturma davranışı olduğunu, önem sırasına göre bunu izleyen diğer yanıtlar ise nesne, oyuncak ya da yazılı materyali gözlerine yakın tutmaya çalışma, resim çizme, oyuncağa, kitaba bakma gibi etkinlikler sırasında nesneyi gözlerine çok yaklaştırma veya nesneye doğru çok eğilme, sıklıkla parlak 1şığa bakma, sürekli ileri-geri sallanma, uzaktaki nesneleri açık net bir şekilde tarif edememe, gözlerinden birini kapatmaya çalışma, etrafında daireler çizerek dönme gibi davranışlar olmuştur. Çocukların şikayetleri arasında ise gözlerinde sık sık yanma ve kaşıntı, gözlerini olağandan fazla kırpıştırma, kısma, kaşlarını çatma, gözlerinin sık sık yaşarması, baş dönmesi, baş ağrısı, yakından bakmayı gerektiren işlerden sonra mide bulantısı, bulanık ve çift görme, göz kapağında sıklıkla şişlik ya da çapaklanma gibi şikâyetler olmuştur. Özyürek (1998) de çocukların gözlerinin önünde bulunan ilgi çekici eşyaları takip edememesi ya da farkına varamaması, uzun süre aynı yere bakma, farklı bir şekilde gözlerini döndürme, sık sık gözlerini ovma ve kaşıma, gözlerini ışıtan kaçırma, gözlerinde titreme, renkli bir resmin renklerini ayıramama, gözlerinde kızarıklık ve yaşarma gibi belirtilerden biri ya da birkaçı görüldüğünde çocukta görme yetersizliği olma riskinin yüksek olduğunu ve bu çocuğun en kısa sürede doktora götürülmesi gerektiğini belirtmiştir.

Görme yetersizliği olan çocukların eğitimlerine ilişkin bulgular arasında çocukların eğitim aldıkları kurumu/kurumlar, eğitime başlama yaşı, özel eğitim hizmet türü ve kurumda eğitim aldıkları modüller hakkındaki bilgileri incelenmiştir. Araştırmaya katılan çocukların çoğunluğunun görme engelliler ilköğretim okuluna devam ettiği, daha sonra ise sırası ile özel eğitim okulu, özel eğitim ve rehabilitasyon merkezi, özel ilköğretim okulunun ya da kolej ve resmi ilköğretim okulları içinde yer alan anaokuluna devam ettikleri görülmektedir. Araştırmaya katılan çocukların yaşları incelendiğinde çoğunluğunun 8-10 yaşlarında olmasının bu sonucun ortaya çıkmasının temel nedeni olduğu düşünülmektedir. Ülkemizde görme yetersizliği olan çocuklar genellikle özel eğitime yönelik okul ve rehabilitasyon merkezlerinde 
eğitim alırken, birçok ülkede kaynaştırma eğitimi ve gezici öğretmenlik uygulamaları daha fazla önem kazanmıştır. Örneğin, Morris ve Sharma (2011) yaptıkları çalışmada görmeyen ve görme yetersizliği bulunan okul öncesi dönemdeki çocukların daha çok gezici öğretmen desteği ile tipik gelişim gösteren akranlarının arasında eğitim aldıklarını vurgulamışlardır.

Görme yetersizliği olan çocukların eğitime başlama ve yararlandıkları özel eğitim hizmet türleri incelendiğinde ise çalışmaya katılan çocukların çoğunun 0-1 yaş gibi erken dönemde eğitime başladıkları görülmektedir. Değerler incelendiğinde görme yetersizliğine sahip çocukların ebeveynlerinin çocuklarının erken yaşlardan itibaren özel eğitim ve rehabilitasyon desteği almasını sağladığı, eğitimlerini ise hem bireysel hem grup eğitimi şeklinde aldıkları dikkati çekmektedir. Araştırmaya katılan çocukların tanılanma zamanlarının çoğunluğunun 0-3 aylar arasında olduğu hatırlandığında, çocukların tanı konduktan sonra hemen eğitime başladıkları görülmektedir. Çocukların devam ettiği eğitim modülleri incelendiğinde ise, en fazla Türkçe ve Matematik Modüllerine devam ettikleri, bunları ise Bağımsız Hareket Becerileri, Psiko-Motor Beceriler, Öğrenmeye Hazırlık, Günlük Yaşam Beceriler ve Sosyal Beceriler Modülleri takip etmektedir. Araştırmaya dahil olan çocukların çoğunun 8-10 yaşlar arasında olması ve erken dönemde eğitime başladıkları dikkate alındığında bu sonucun ortaya çıkması beklenen bir durum olmuştur.

Görme yetersizliği olan çocukların aile destek bilgilerine ilişkin bulgular arasında ise ebeveynlerin aile eğitim çalışmalarına katılma durumu, aile eğitim çalışmalarının türü, aile eğitimini veren uzmanlar ve eğitim konuları incelenmiştir. Araştırmaya katılan ebeveynlerin çoğunluğu aile eğitim çalışmalarına katılmıştır. Ebeveynin katıldığı aile eğitim çalışmaları sırası ile çocuklarının devam ettiği özel eğitim ve rehabilitasyon merkezleri tarafından yapılan aile eğitim çalışmaları, doktor tarafından verilen eğitim, çocuklarının devam ettiği özel eğitim ve rehabilitasyon merkezinde diğer ailelerle birlikte yapılan grup aile eğitimi çalışmaları olduğu görülmektedir. Aile eğitim çalışmalarını daha çok çocuklarının devam ettiği merkezdeki görme engelliler öğretmenlerinin verdikleri görülmektedir. Araştırmaya katılan ebeveynlerden sadece üç ebeveyn gibi çok az bir kısmının seminere katıldığı belirlenmiştir. Görüldüğü gibi aileler daha çok çocukları özel eğitim ve rehabilitasyon merkezinde eğitim almaya başladığı zaman en fazla özel eğitim öğretmenlerinden bireysel olarak destek almakta, bunu ise grup aile eğitim çalışmaları izlemektedir. Görme yetersizlikleri ile ilgili düzenlenen seminerlere katılım ise çok sınırlı bulunmuştur. Bunun da bu konularda düzenlenen seminerlerin sayısının az olması, seminer duyurularının yeterince ailelere ulaşmaması ya da ailelerin çeşitli nedenlerle katılımlarının sınırlı olmasından kaynaklandığı düşünülebilir. Ailelerin destek aldığı aile eğitim 
konuları incelendiğinde ise, önem sırasına göre; çocuğuna davranış şekilleri, çocukla iletişim, çocuğunun gelişimini destekleme, ev ortamını düzenleme, oyun, çocuğuyla konuşma, oyuncak alma/hazırlama ve çocuğunun duyularını destekleme konuları olduğu belirlenmiştir. Görme yetersizliği tespit edilen çocukların ebeveynlerinin çocukları ile iletişim kurmak ve çocuklarının gelişimlerini desteklemek için aile eğitim çalışmalarına oldukça talep gösterdikleri söylenebilir. Murdoch, (2002) hem işitmeyen hem de görmeyen çocuklarla yaptığı projede ebeveyn-çocuk etkileşimlerini ve aile ilişkilerini desteklemeye odaklanan programların hazırlanması erken dönemde bireyselleştirilmiş müdahalenin sağlanması, erken müdahale sürecinin her aşamasında ebeveynlerin eğitime aktif katılımlarının sağlanmasının gerektiğini vurgulamıştır. Giangreco ve arkadaşları (1991) ise görme ve işitme yetersizliği olan çocukların aileleriyle yaptıkları görüşmelerde, bu çocukların eğitim sisteminde "müfredat, eğitim, genel eğitim okulları/sınıflarında kaynaştırılması ve ebeveynlerin çocuklarıyla iletişimi konusunda desteklenmesi gerektiğini belirlemişlerdir.

\section{Öneriler}

Çalışma sonuçları dikkate alınarak aşağıdaki öneriler sunulabilir.

$\checkmark$ Görme yetersizliği olan çocukların çoğunda görme yetersizliği 0-3 aylar arasında, bunu hamilelik dönemi, sonra ise 4-6 aylar gibi erken dönemde fark edildiği görülmektedir. Erken dönemde fark edilmesiyle de bu çocuklar erken dönemde desteklenmektedir. $\mathrm{Bu}$ sonuç düşünüldüğünde bebeklerin doğduktan sonra erken aylarda göz taramalarının önemi ortaya çıkmaktadır. Erken dönemde gerekli muayene ve tedavinin yapılması ile görme problemleri için gerekli önlemler alınabilir.

$\checkmark$ Görme yetersizliğinin büyük oranda doktorun söylemesiyle fark edildiğini, bunu ebeveynler tarafından çocuğunun davranışlarından fark edildiği ve küçük bir kısmının ise genel kontroller sırasında fark edildiği belirlenmiştir. $\mathrm{Bu}$ da görme yetersizliğini belirlemede ailelerin bilinçlendirilmesi konusundaki yetersizlikleri göstermektedir. Ailelerin görme problemleri, görme yetersizliklerin belirtileri ve bu çocukların davranış özellikleri gibi konularda erken dönemde bilinçlendirilmesi ve ailelerin bilinçlendirilmesine yönelik medya ve çocuk doktorlarına destek sunulabilir.

$\checkmark$ Görme yetersizliği olan çocukların erken dönemde tanılanmasıyla eğitime başladıkları görülmektedir. Erken dönemde görme yetersizliği olan bebeklerin çocukların gelişimlerinin desteklenmesine yönelik aile katılımının daha etkili sağlanabileceği programlar geliştirilebilir. 
$\checkmark$ Araştırmaya katılan ebeveynlerin çoğu aile eğitim çalışmalarına katılmıştır. Bu eğitimi de daha çok bireysel şekilde özel eğitim öğretmenlerinden aldıkları görülmektedir. Bu eğitimler de genellikle rehberlik şeklinde sürdürülmektedir. Aile eğitim çalışmalarında çoğu özel eğitim merkezi ve rehabilitasyon merkezlerinde grup aile eğitim çalışmaları da önem kazanmış olsa da bu eğitimlerin sıklığının arttırılması, aile katılımlarının özendirilmesi ve sağlanması önemlidir. Ayrıca bu eğitimlere sadece öğretmenler değil, bu alanda çalışan uzmanların katılımı da sağlanabilir.

$\checkmark$ Günümüzde teknoloji büyük önem kazanmıştır. Çocukların ve ailelerin eğitimlerinde de teknolojik cihazların kullanımı arttırılabilir. Eğitim kurumlarında öğretmenlerin bu çocuklar ve aileleri ile iletişim ve destek konularında gereksinimleri belirlenerek, hizmet içi eğitim çalışmaları ile öğretmenler desteklenebilir.

\section{KAYNAKÇA}

MEB. (2013). M.E.B. Çocuk gelişimi ve eğitimi, görme engelliler. Ankara: M.E.B.

Allen, K. E. and Cowdery, G. E. (2005). The exceptional child, inclusion in early childhood education. United Kingtom, U.S.A.: Thomson, Delmar Learning.

Aytekin, Ç. (2014). Ev temelli erken müdahale programının geliştirilmesi: Bir vaka çalışması. (Yayınlanmamış Doktora Tezi) Hacettepe Üniversitesi, Ankara.

Aytekin, Ç. ve Bayhan, P. (2015). Erken müdahalede uygulama basamakları. H.Ü. Săgllk Bilimleri Fakültesi Dergisi, 2 (2), 1-14.

Basch, C. E. (2011). Vision and the achievement gap among Urban minority youth. Journal of School Health, 81(10), 599-605.

Baş, A. B. (1993). Türkiye'de ve Dünya'da körlüğün nedenleri ve alınması gereken önlemler. Özel Eğitim Dergisi, 1(3), 48-51.

Başakçı Çalık, B., Kitiş, A., Cavlak, U. and Oğuzhanoğlu, A. (2012). The impact of attention training on children with low vision: A randomized trial. Turk J Med Sci, 42(1), 11861193.

Berg, A. O., Allan, J. D., Calonge, N., Frame, P., Garcia, J., Harris, R., Johnson, M. S., Klein, J. D., Loveland-Cherry, C., Moyer, V. A., Orleans, C. T., Siu, A. L., Teutsch, S. M., Westhoff, C., and Woolf, S. H. (2004). Screening for visual impairment in children younger than age 5 years: Recommendation statement. Annals of Family Medicine, 2(3), 263-266. DOI: 10.1370/afm.193.

Büyüköztürk, Ş., Kılıç Çakmak, E., Akgün, Ö.E., Karadeniz, Ş. ve Demirel, F. (2012). Bilimsel araştırma yöntemleri. Ankara: Pegem Akademi.

Dale, N. and Sonksen, P. (2002). Developmental outcome, including setback, in young children with severe visual impairment. Developmental Medicine \& Child Neurology, 44, 613622. 
Davidson, P. and Harrison, G. (2000). Th e eff ectiveness of early intervention for children with visual impairments. İçinde M. J. Guralnick (Ed.) The eff ectiveness of early intervention (s.483-495). Baltimore: Paul H. Brookes Publishing.

Eckstein, M. B., Foster, A. and Gilbert, C. E. (1995). Causes of childhood blindness in Sri Lanka: Results from children attending six schools for the blind. British Journal of Ophthalmology, 79, 633-636.

Farrenkopf, C., Howze, Y. ve Sowell, V. (1995). Social skills development for preschool children with visual impairments. Annual International Convention of the Council for Exceptional Children (73 ${ }^{\text {rd }}$, Indianapolis, IN, April 5-9, 1995) ED 384176.

Fazzi, E., Lanners, J., Danova, S., Ferrarri-Ginevra, O., Gheza, C., Luparia, A., Balottin, U. \& Lanz, G. (1999). Stereotyped behaviours in blind children. Brain \& Development, 21, 522-528.

Ferreira, V. \& Albuquerque, C. P. (2017). Adaptation of a developmental test to accommodate young children with low vision. Journal of Visual Impairment \& Blindness, MarchApril, 97-111.

Giangreco, M. F., Cloninger, C. J., Mueller, P. H., Yuan, S. and Ashworth, S. (1991). Perspectives of parents whose children have dual sensory impairments. The Association for Persons with Severe Handicaps, 16(1), 14-24.

Gilbert, C. and Awan, H. (2003). Blindness in children, BMJ, 327 (7418), 760-761. DOI: 10.1136/bmj.327.7418.760

Gilbert, C. and Foster, A. (2001). Childhood blindness in the context of VISION 2020-The Right to Sight. Bulletin of the World Health Organization, 79(3), 227-232.

Gogate, P., Gilbert, C. and Zin, A. (2011). Severe visual impairment and blindness in infants: Causes and opportunities for control. Middle East Afr J Ophthalmol. 18(2), 109-114. DOI: 10.4103/0974-9233.80698.

Haibach, P. S., Wagner, M. O. and Lieberman, L. J. (2014). Determinants of gross motor skill performance in children with visual impairments. Research in Developmental Disabilities, 35, 2577-2584.

Hallahan, J. M. and Kauffman, D. P. (2003). Exceptional learners (Introduction to special education). U.S.A: Allyn and Bacon.

Heward, W. L. (2000). Exceptional children: An introduction to special education. U.S.A.: Merrill.

Howard, V. F., Williams, B. ve Lepper, C. E. (2011). Duygusal yetersizliği olan çocuklar ve enfeksiyonlar. İçinde G. Akçamete (Çev. Ed). Özel Gereksinimi Olan Küçük Çocuklar. Ankara: Nobel Yayınları.

Kaur, G., Koshy, J., Thomas, S., Kapoor, H., Zachariah, J. G. and Bedi, S. (2016). Vision screening of school children by teachers as a community based strategy to address the challenges of childhood blindness. Journal of Clinical and Diagnostic Research. 10(4), NC09-NC14. DOI: 10.7860/JCDR/2016/18939.7628.

Kello, A B and Gilbert, C. (2003). Causes of severe visual impairment and blindness in children in schools for the blind in Ethiopia. Br J Ophthalmol, 87, 526-530.

Kesiktaş, D. A. (2009). Görme engellilerde erken çocukluk özel eğitimi: Sorunlar ve çözümler. Kuram ve Uygulamada Ĕ̈itim Bilimleri, 9(2), 799-832. 
Kiarie, M. W. (2004). Education of students with visual impairments in Kenya: Trends and issues. International Journal of Special Education, 19(2), 16-22.

Kirk, S. A., Gallagher, J. J. and Anastasiow, N. J. (1993). Educating exceptional children. U.S.A.: Houghton Mifflin

Lee, J., Kotsopoulos, D. ve Stordy, C. (2012). Mathematically relevant input during play of a caregiver with a visual impairment and her toddler. IJEC, 44, 71-90.

Lewis, V. (1987). Development and Handicap (2. Bask1). USA: Blackwell.

Liberman, L. J. and MacVibar, J. M. (2003). Play and recreational habits of youths who are deaf-blind. Journal of Visual Impairment and Blindness, December, 755-768.

Lima, A. L. and Nunes, R. T. D. (2015). Phonological profile of children with low vision from 6 to 9 years old at an institution for the blind in the city of Salvador. Rev. CEFAC. SetOut, 17(5), 1490-1498.

Loots, G., Devisé, I. and Sermijn J. (2003). The interaction between mothers and their visually impaired infants: An intersubjective developmental perspective. Journal of Visual Impairment and Blindness, 97(7), 403-417.

Lo'Pez-Justicia, M. D., Marti'Nez, M. C. P. and Medina, A. C. (2005). Self-concept in lowvision children and their peers without visual problems. Self and Identity, 4, 305 - 309, DOI: $10.1080 / 15298860500146051$.

Mahoney, G., Boyce, G., Fewell, R. R., Spiker, D. and Wheeden, C. A. (1998). The relationship of parent-child interaction to the effectiveness of early intervention services for at-risk children and children with disabilities. Topics in Early Childhood Special Education, 18(1), 5-17.

McAllister, R. and Gray, C. (2006). Low vision: Mobility and independence training for the early years child. Early Child Development and Care, 1-14. DOI: 10.1080/03004430600594096.

Morris, C. and Sharma, U. (2011). Facilitating the inclusion of children with vision impairment: Perspectives of itinerant support teachers. Australasian Journal of Special Education, 35(2), 191-203. DOI 10.1375/ajse.35.2.191.

Muhit, M. A., Shah, S. P., Gilbert, C. E. and Foster, A. (2007). Causes of severe visual impairment and blindness in Bangladesh: A study of 1935 children. Br J Ophthalmol, 91, 1000-1004. DOI: 10.1136/bjo.2006.108019.

Murdoch, H. (2002). Early intervention for children who are deafblind. Sense Campaigns, 1113 Clifton Terrace, Finsbury Park, London, N4 3SR, www.sense.org.uk/reachout.

Nergiz, H. (2013). Görme engelli çocuk ebeveynlerinin yaşadığ güçlüklerin belirlenmesi ve tükenmişlik ile yaşam doyumuna yönelik yordayıcı değişkenler (Yayınlanmamış Yüksek Lisans Tezi) Hacettepe Üniversitesi, Ankara.

Özgür, İ. (2013). Engelli çocuklar ve eğitimi, özel eğitim. Adana: Karahan Kitapevi.

Özyürek, M. (1998). Görme engelliler. İçinde M. Özyürek (Ed) Özel Eğitim (s. 129-154). Eskişehir: TC Anadolu Üniversitesi Yayınları.

Pinquart, M. and Pfeiffer, J. P. (2013). Identity development in German adolescents with and without visual impairments. Journal of Visual Impairment \& Blindness, SeptemberOctober, 33-349. 
Prechtl, H. F. R., Cioni, G., Einspieler, C., Bos, A. F. and Ferrari, F. (2001). Role of vision on early motor development: lessons from the blind. Developmental Medicine \& Child Neurology, 43, 198-201.

Ramey, C. T. and Ramey, S. L. (1998). Early intervention and early experience, American Psychologist, 53(2), 109-120.

Tsai, L.-T., Meng, L.-F., Wu, W.-C., Jang, Y. and Su, Y.-C. (2013). Effects of visual rehabilitation on a child with severe visual impairment. American Journal of Occupational Therapy, 67, 437-447.

Tuncer, T. (2014). Görme yetersizliği olan çocuklar. İçinde S. Vuran (Ed). Özel Ĕgitim (s. $297-$ 329). Ankara: Maya Akademi.

Smith, D. D. (2001). Introduction to special education, teaching in an age of oppornity. Singapore: Allyn \& Bacon.

Solebo, A. L. and Rahi, J. (2014). Epidemiology, aetiology and management of visual impairment in children. Arch Dis Child, 99, 375-379. DOI:10.1136/archdischild-2012303002.

Sönmez, M. (2013). Okul-öğretmen-aile iş birliği. İçinde A. Cavkaytar. (Ed). Özel Ĕ̆itimde Aile Eğitimi ve Rehberliği. (s. 215-239) Ankara: Vize Yayıncılık.

Wiskochil, B., Lieberman, L. J., Wilson, C. H. and Petersen, S. (2007). The effects of trained peer tutors on the physical education of children who are visually impaired, Journal of Visual Impairment \& Blindness (JVIB), 101(6), 1-18.

Varol, N. (1996). Erken Çocukluk Dönemindeki Görme Yetersizliği Olan Çocukların Ĕ̆itimi, Ankara: Karatepe Yayınları.

Yıldırım Doğru, S. (2013). Erken çocukluk özel eğitimi. İçinde A. Cavkaytar. (Ed). Özel Ĕ̈itim. (s. 317-336). Ankara: Vize Yayıncilık. 